\title{
Bioassay Guided Fractionation and $\alpha$-Amylase Inhibitory Activity of Flavanoid Isolated from Pinus roxburghii Sarg.
}

Pawan Kaushik ${ }^{1}$, Gulshan Singh ${ }^{2}$, Sukhbir Lal Khokra ${ }^{1}$ and Dhirender Kaushik ${ }^{2 *}$

${ }^{1}$ Institute of Pharmaceutical Sciences, Kurukshetra University, Kurukshetra-136119, Haryana, India

${ }^{2}$ Department of Chemistry, Kurukshetra University, Kurukshetra-136119, Haryana, India

\begin{abstract}
Pinus roxburghii Sarg. is a traditional plant used in the treatment of diabetes mellitus ethnopharmacology in India and Africa. In this written report, we looked into the antidiabetic activity using $\alpha$-amylase inhibitory assay on extracts from the bark of Pinus roxburghii Sarg. by bioassay guided fractionation. The ethanol extract ( $43.4 \%$ inhibition) and the isolated compound (49.6\% inhibition) exhibited significant enzyme inhibitory activity against $\alpha$-amylase. This is reported, from this plant, for the first time. The ${ }^{1} \mathrm{H}$ and ${ }^{13} \mathrm{C}$ NMR, IR and mass spectral studies of isolated compound suggested it as quercetin. Our study revealed, for the first time, the isolation and a-amylase inhibitory activity of quercetin from Pinus roxburghii Sarg. bark.
\end{abstract}

Keywords: Pinus roxburghii Sarg.; a-amylase; Quercetin; Diabetes; Ethanolic extract; Bioassay guided isolation

\section{Introduction}

Diabetes mellitus is a metabolic issue portrayed by perpetual hyperglycemia or expanded blood glucose levels with unsettling influences in fat, starch and protein digestion system coming about because of total or relative absence of insulin secretion [1]. Postprandial hyperglycemia is a noticeable and early imperfection in diabetes [2] which can thus prompt different auxiliary complexities including danger component for cardiovascular ailments [3]. One helpful way to diminishing the hyperglycemia, particularly after a feast, is to retard and lessen the assimilation and retention of ingested carbohydrates through the hindrance of carbohydrate hydrolyzing enzymes ( $\alpha$-amylase) in the digestive system. Accordingly, these inhibitors could diminish the postprandial climb in blood glucose concentration [4]. a-Amylase is one of the enzymes in the digestive framework that catalyzes the breakdown of starch to maltose lastly to glucose, which is the main sugar that can be used by the body [5]. Enzyme inhibitors can be a potential focus in numerous ranges of ailment control and treatment, as enzymes catalyze the most vital biochemical pathways [6].

The greater part of the monetarily accessible amylase and glucosidase inhibitors are of microbial origin. Their utilization has been restricted because of their symptoms, for example, fast and loose bowels because of colonic maturation of undigested sugar [7,8]. At the point when contrasted with the microbial partners, amylase inhibitors from therapeutic plant are extensively sheltered and compelling. Among 1200 plants which have hypoglycemic property, just $30 \%$ of the opposition to diabetic plants have been pharmacologically tried and explored [9]. In this manner, $\alpha$-amylase inhibitors can be utilized to treat disease such as diabetes, obesity and hyperlipaemia [10].

Pinus roxburghii Sarg. (Family: Pinacae) is a pine inhabitant to the Himalaya [11]. Pinus roxburghii Sarg. has reported to exhibit different pharmacological activities such as anti-inflammatory, analgesic [12] anticonvulsant [13], antimicrobial [14] and anticancer [15] activities. Indian and African healers are using bark and leaf of Pinus roxburghii Sarg. to treat diabetes [16]. Our recent in silico studies demonstrated that secoisoresinol and different phytoconstituents from bark of Pinus roxburghii Sarg. is compelling against aldose reductase, [17] which is mainly responsible for secondary complications of diabetes [18]. Therefore, in the present study bioassay guided fractionation of ethanolic extract and $\alpha$-amylase inhibitory activity of isolated flavonoid was evaluated.

\section{Materials and Methods}

\section{General experimental procedures}

The IR spectrum was obtained from a Perkin Elmer, Model: Spectrum-100. NMR experiments were carried out on a Bruker $300 \mathrm{MHz}$ spectrometer using tetramethylsilane (TMS) as internal standard. The ESI-MS were recorded on an Agilent Chem station Gas Chromatograph equipped and coupled to a mass detector with a polar column.

\section{Collection of plant material}

The bark of Pinus roxburghii Sarg. were gathered from the hilly region of Morni, District Panchkula, Haryana, and was authenticated by Dr. A.K Sharma, Sr. Scientist at Department of Natural Product, FRI, Dehradun, Uttarakhand, India, where a voucher specimen no. 129 FHH was deposited for future reference.

\section{Extraction, isolation and chromatography}

Shade dried coarse powdered bark of Pinus roxburghii Sarg. in a quantity sufficient as per the volume of the extractor was packed in a thimble (made of filter paper sheet) and sequentially extracted with petroleum ether, chloroform, ethyl acetate and ethanol. A sufficient volume of solvent was added to the reservoir, and hot continuous extraction process in a soxhlet extractor was started. This extraction process was continued for about 48 hours or until alcohol coming down the siphoning tube became colorless. The over abundance of solvent was distilled under reduced pressure using a rotatory vacuum evaporator. (Heidolph Laborota 4011, digital). All the extracts were evaluated for their potential to inhibit the enzyme $a$-amylase. As ethanolic extract proved to be most promising extract was further subjected to portioning between $n$-butanol and water. The n-butanol soluble

*Corresponding author: Dhirender Kaushik, Institute of Pharmaceutical Sciences Kurukshetra University, Kurukshetra, Haryana, India, Tel: +919416055522, +919467648830; E-mail: dkaushik.apti@gmail.com

Received June 18, 2015; Accepted June 26, 2015; Published June 28, 2015

Citation: Kaushik P, Singh G, Khokra SL, Kaushik D (2015) Bioassay Guided Fractionation and a-Amylase Inhibitory Activity of Flavanoid Isolated from Pinus roxburghii Sarg. Nat Prod Chem Res 3: 179. doi:10.4172/2329-6836.1000179

Copyright: ( 2015 Kaushik P, et al. This is an open-access article distributed under the terms of the Creative Commons Attribution License, which permits unrestricted use, distribution, and reproduction in any medium, provided the original author and source are credited. 
Citation: Kaushik P, Singh G, Khokra SL, Kaushik D (2015) Bioassay Guided Fractionation and a-Amylase Inhibitory Activity of Flavanoid Isolated from Pinus roxburghii Sarg. Nat Prod Chem Res 3: 179. doi:10.4172/2329-6836.1000179

Page 2 of 3

fraction thus obtained was subjected to column chromatography over silica gel (number 60-120) and eluted gradually with chloroform:ethyl acetate:methanol (5:4:1). Fractions were pooled according to their similarity in behavior on thin layer chromatography. The fractions were concentrated to finally obtain compound $1(21 \mathrm{mg})$. The compound 1 was dissolved either in methanol, chloroform, or dimethyl sulfoxide depending on its solubility for analysis. The structure of the isolated compound was elucidated from the data obtained from IR, ${ }^{1} \mathrm{H}-\mathrm{NMR}$ and ${ }^{13} \mathrm{C}-\mathrm{NMR}$ spectra.

\section{Alpha amylase inhibitory activity}

The alpha amylase inhibitory activity was carried out by the method devised by [19]. Briefly, the total assay mixture containing $200 \mu \mathrm{l}$ of $0.02 \mathrm{M}$ sodium phosphate buffer, $20 \mu \mathrm{l}$ of enzyme ( $\alpha$-amylase) and the plant extracts at a concentration of $100 \mu \mathrm{g} / \mathrm{ml}$ were incubated for $10 \mathrm{~min}$ at room temperature followed by addition of $200 \mu \mathrm{l}$ of $1 \%$ starch in all the test tubes. The reaction was terminated with addition of $400 \mu \mathrm{l}$ of di-nitro salicylic acid color reagent, placed in boiling water bath for $5 \mathrm{~min}$, cooled to room temperature and diluted with $15 \mathrm{ml}$ of distilled water and the absorbance measured at $540 \mathrm{~nm}$ (SystronicUV-VIS spectrophotometer). The control samples were also prepared accordingly without any plant extracts and were compared with the test samples containing the plant extracts prepared with different solvents. The results were expressed as $\%$ inhibition calculated using the formula:

Inhibition activity $(\%)=\frac{\operatorname{Abs}(\text { control })-\operatorname{Abs}(\text { extract })}{\operatorname{Abs}(\text { control })} \times 100$

\section{Statistical analysis}

Data are expressed as mean \pm S.E.M. The data was analyzed by one-way analysis of variance (ANOVA) followed by Dunett's $t$ test to ascertain the level of significance using GraphPad InStat version 3.05 for Windows. Values of $p<0.05$ were considered statistically significant.

\section{Results}

\section{Alpha amylase inhibitory activity}

Acarbose (at a concentrations $100 \mu \mathrm{g} / \mathrm{mL}$ ) showed $56.7 \%$ inhibitory effects on the $\alpha$-amylase activity (Table 1 ). The Compound 1 (at a concentration $100 \mu \mathrm{g} / \mathrm{mL}$ ) exhibited $49.6 \%$ of $\alpha$-amylase inhibitory activity. The ethanol, ethylacetate and chloroform extracts of Pinus roxburghii Sarg. (at a concentration $100 \mu \mathrm{g} / \mathrm{mL}$ ) exhibited $43.4 \%, 40.1 \%$ and $30.5 \%$ of $a$-amylase inhibitory activity respectively. However, the pet-ether extract did not show a-amylase inhibitory activity. Both ethanol extracts and compound 1 showed appreciable $\alpha$-amylase inhibitory effects when compared with acarbose (56.7 \%).

\section{Identification of the chemical structure of the isolated compound}

The compound was characterized by comparison of their spectroscopic data with those reported in literature. From these data and those presented in Table 2, compound 1 was identified as quercetin.

Compound 1: IR $\left(\mathrm{cm}^{-1}\right)$ : $3433(-\mathrm{OH}), 1651(-\mathrm{C}=\mathrm{O}), 1026(-\mathrm{C}-\mathrm{O})$; ${ }^{1} \mathrm{H}-\mathrm{NMR}\left(300 \mathrm{MHz}, \mathrm{CDCl}_{3}, \delta\right): 6.17$ (s, 1H, 6-H), 6.38 (s, 1H, 8-H), 6.88 (d, $\left.J=8.4 \mathrm{~Hz}, 1 \mathrm{H}, 5^{\prime}-\mathrm{H}\right), 7.55\left(\mathrm{~d}, J=8.4 \mathrm{~Hz}, 1 \mathrm{H}, 6^{\prime}-\mathrm{H}\right), 7.7\left(\mathrm{~s}, 1 \mathrm{H}, 2^{\prime}-\mathrm{H}\right)$, 9.27 (bs, 4H, 5, 6, 3', $\left.4^{\prime}-\mathrm{OH}\right), 12.43$ (s, 1H, 3-OH); ${ }^{13} \mathrm{C}-\mathrm{NMR}(75 \mathrm{MHz}$, $\left.\mathrm{CDCl}_{3}, \delta\right): 92.84,97.69,102.53,114.51,114.97,119.51,121.56,135.20$, $144.45,146.19,147.06,155.69,160.34,163.34,175.26$.

Anal. Calcd. for : $\mathrm{C}_{15} \mathrm{H}_{10} \mathrm{O}_{7} ; \mathrm{C}, 59.61 ; \mathrm{H}, 3.33$; Found: C, 59.48; $\mathrm{H}$, 3.11; O, MS (EI, m/z): $303.14(\mathrm{M}+1)^{+}$. The spectral data of compound
1 (Figure 1) closely matched that of 3,3', 4',5,7-pentahydroxyflavone (quercetin) reported in the literature $[20,21]$.

\section{Discussion and Conclusion}

In this study, quercetin, showed the highest $\alpha$-amylase inhibitory activity. The $\%$ inhibition values for $\alpha$-amylase inhibition by quercetin and acarbose (as the positive control) were 49.6 and 56.7 respectively. This is the first report of the $\alpha$-amylase inhibitory activity of quercetin, the isolated compound from Pinus roxburghii Sarg. Also, previous studies have reported the isolation of sitosterol [22], tannins [23], hexacosyferrulate [24] from Pinus roxburghii Sarg., but the isolation of quercetin from the plant has not previously been reported. Moreover quercetin isolated from other plants has shown prominent antidiabetic activity [25]. This study shows the possibility of using ethanol

\begin{tabular}{|l|l|l|l|}
\hline Extract & Concentration & Absorbance & $\begin{array}{l}\text { a-amylase (\% } \\
\text { inhibition) }\end{array}$ \\
\hline Control & & $0.969 \pm 0.06$ & --- \\
\hline Compound 1 & $100 \mu \mathrm{g} / \mathrm{ml}$ & $0.443 \pm 0.02$ & 51.1 \\
\hline Ethanol & $100 \mu \mathrm{g} / \mathrm{ml}$ & $0.518 \pm 0.17$ & 43.4 \\
\hline Ethyl acetate & $100 \mu \mathrm{g} / \mathrm{ml}$ & $0.550 \pm 0.02$ & 40.1 \\
\hline Chloroform & $100 \mu \mathrm{g} / \mathrm{ml}$ & $0.643 \pm 0.03$ & 30.5 \\
\hline n-Butanol & $100 \mu \mathrm{g} / \mathrm{ml}$ & $0.458 \pm 0.14$ & 49.6 \\
\hline Pet ether & $100 \mu \mathrm{g} / \mathrm{ml}$ & --- & No activity \\
\hline Acarbose & $100 \mu \mathrm{g} / \mathrm{ml}$ & $0.389 \pm 0.14$ & 56.7 \\
\hline
\end{tabular}

Table 1: Enzyme inhibition activity of isolated constituents.

\begin{tabular}{|c|c|c|c|c|}
\hline \multirow{2}{*}{ Carbon no } & \multicolumn{2}{|c|}{ Literature data } & \multicolumn{2}{|c|}{ Isolated compound data } \\
\hline & $\delta^{13} \mathrm{C}$ & $\delta^{1} \mathrm{H}$ & $\delta^{13} \mathrm{C}$ & $\delta^{1} \mathrm{H}$ \\
\hline $\mathrm{C}-2$ & 146.9 & & 146.19 & \\
\hline C-3 & 135.2 & & 135.20 & \\
\hline C-4 & 176.0 & & 175.26 & \\
\hline C-5 & 160.9 & & 160.34 & \\
\hline C-6 & 98.3 & $6.18(\mathrm{~d}, \mathrm{~J}=2.0 \mathrm{~Hz})$ & 97.69 & $6.17(s)$ \\
\hline $\mathrm{C}-7$ & 164 & & 163.34 & \\
\hline C-8 & 93.5 & $6.37(\mathrm{~d}, \mathrm{~J}=2.0 \mathrm{~Hz})$ & 92.84 & $6.38(s)$ \\
\hline C-9 & 156.3 & & 155.69 & \\
\hline $\mathrm{C}-10$ & 103.2 & & 102.53 & \\
\hline C-1' & 122.2 & & 121.56 & \\
\hline C-2' & 115.0 & $7.73(\mathrm{~d}, \mathrm{~J}=2 \mathrm{~Hz})$ & 114.51 & 7.7 (s) \\
\hline C-3' & 145.2 & & 144.45 & \\
\hline C-4' & 147.8 & & 147.06 & \\
\hline C-5 & 115.8 & $6.87(\mathrm{~d}, \mathrm{~J}=8.0 \mathrm{~Hz})$ & 114.97 & $6.88(\mathrm{~d}, \mathrm{~J}=8.4 \mathrm{~Hz})$ \\
\hline C-6' & 120.1 & $7.62(\mathrm{dd}, \mathrm{J}=2.0,8.0 \mathrm{~Hz})$ & 119.51 & $7.55(\mathrm{~d}, \mathrm{~J}=8.4 \mathrm{~Hz})$ \\
\hline $3-\mathrm{OH}$ & & $12.49(\mathrm{~s})$ & & $12.43(\mathrm{~s}, 5-\mathrm{OH})$ \\
\hline $5-\mathrm{OH}$ & & 9,6 (br s) & & 9.27 (br s) \\
\hline
\end{tabular}

br s-broad singlet, j=coupling contant, s-singlet, d-doublet, dd-doublet of doublet Table 2: ${ }^{1} \mathrm{H}$ NMR and ${ }^{13} \mathrm{C}$ NMR data of isolated compound.<smiles>O=c1c(O)c(-c2ccc(O)c(O)c2)oc2cc(O)cc(O)c12</smiles>

Figure 1: The spectral data of compound 1. 
Citation: Kaushik P, Singh G, Khokra SL, Kaushik D (2015) Bioassay Guided Fractionation and a-Amylase Inhibitory Activity of Flavanoid Isolated from Pinus roxburghii Sarg. Nat Prod Chem Res 3: 179. doi:10.4172/2329-6836.1000179

extract of Pinus roxburghii Sarg. and quercetin to decrease postprandial hyperglycaemia. Also, the study justifies the use of Pinus roxburghii Sarg. in the management of diabetes mellitus by Indian and African healers.

\section{References}

1. Alberti KG, Zimmet PZ (1998) Definition, diagnosis and classification of diabetes mellitus and its complications. Part 1: diagnosis and classification of diabetes mellitus provisional report of a WHO consultation. Diabet Med 15: 539-553.

2. Carroll MF, Gutierrez A, Castro M, Tsewang D, Schade DS (2003) Targeting postprandial hyperglycemia: a comparative study of insulinotropic agents in type 2 diabetes. J Clin Endocrinol Metab 88: 5248-5254.

3. Slama G, Elgrably F, Sola A, Mbemba J, Larger E (2006) Postprandia glycaemia: a plea for the frequent use of delta postprandial glycaemia in the treatment of diabetic patients. Diabetes Metab 32: 187-192.

4. Puls W, Krause HP, Müller L, Schutt H, Sitt R, et al. (1984) Inhibitors of the rate of carbohydrate and lipid absorption by the intestine. Int $\mathrm{J}$ Obes Suppl 1 : 181-190.

5. Heidari R, Zareae S, Heidarizadeh M (2005) Extraction, Purification, and Inhibitory Effect of Alpha-Aylase Inhibitor from Wheat (Triticum aestivum var. zarrin). Pakistan Journal of Nutrition 4: 101-105.

6. Kim SD, Nho HJ (2004) Isolation and characterization of alpha-glucosidase inhibitor from the fungus Ganoderma lucidum. J Microbiol 42: 223-227.

7. Kusaba-Nakayama M, Ki M, Kawada E, Sato M, Ikeda I, et al. (2001) Intestinal absorbability of wheat allergens, subunits of a wheat alpha-amylase inhibitor, expressed by bacteria. Biosci Biotechnol Biochem 65: 2448-2455

8. Najafian M, Ebrahim-Habibi A, Hezareh N, Yaghmaei P, Parivar K, et al. (2011) Trans-chalcone: a novel small molecule inhibitor of mammalian alpha-amylase. Mol Biol Rep 38: 1617-1620.

9. Ayyanar M, Sankarasivaraman K, Ignacimuthu S (2008) Traditional herbal medicines used for the treatment of diabetes among two major groups in south Tamilnadu India. Ethnobotanical leaflets 12: 276-280.

10. Franco OL, Rigden DJ, Melo FR, Grossi-De-Sá MF (2002) Plant alpha-amylase inhibitors and their interaction with insect alpha-amylases. Eur J Biochem 269 : 397-412.

11. Kaushik P, Kaushik D, Khokra SL (2013) Ethnobotany and phytopharmacology of Pinus roxburghii Sargent: a plant review. J Integr Med 11: 371-376.
12. Kaushik D, Kumar A Kaushik P, Rana AC (2012) Analgesic and AntiInflammatory Activity of Pinus roxburghii Sarg. Adv Pharmacol Sci 2012 245431

13. Kaushik D, Kumar A, Kaushik P, Rana AC (2012) Anticonvulsant activity of alcoholic extract of bark of Pinus roxburghii Sarg. Zhong Xi Yi Jie He Xue Bao 10: $1056-1060$.

14. Kaushik D, Kaushik P, Kumar A, Rana AC, Sharma C, et al. (2013) GC-MS Analysis and Antimicrobial Activity of Essential Oil of Pinus roxburghii Sarg from Northern India. Journal of Essential Oil Bearing Plants 16: 563-567.

15. Kaushik P, Khokra S, Rana A, Kaushik D (2015) Evaluation of Anticance Activity of Pinus roxburghii Sarg. Against IMR-32 Human Neuroblastoma Cancer Cell Line. International Journal of Pharmaceutical and Clinical Research 7: 105-108.

16. Monique SJ, Simmonds, Melanie-Jayne RH (2005) Plants used in the treatment of Diabetes. CRC Press, Taylor Francis Group, Boca Raton. U.S.A.

17. Kaushik P, Khokra SL, Rana AC, Kaushik D (2014) Pharmacophore Modeling and Molecular Docking Studies on Pinus roxburghii as a Target for Diabetes Mellitus. Adv Bioinformatics 2014: 903246.

18. Muthenna P, Suryanarayana P, Gunda SK, Petrash JM, Reddy GB (2009) Inhibition of aldose reductase by dietary antioxidant curcumin: mechanism of inhibition, specificity and significance. FEBS Lett 583: 3637-3642.

19. Miller GL (1959) Use of Dinitrosalicylic Acid Reagent for Determination of Reducing Sugar. Analytical Chemistry 31: 426-428.

20. Foo LY, Lu Y, Molan AL, Woodfield DR, McNabb WC (2000) The phenols and prodelphinidins of white clover flowers. Phytochemistry 54: 539-548.

21. Wawer I, Zielinska A (2001) ${ }^{13} \mathrm{C}$ CP/MAS NMR studies of flavonoids. Magnetic Resonance in Chemistry 39: 374-380.

22. Beri RM (1970) Chemical constituents of the bark of Pinus roxburghii Sargent. Indian J Chem 8: 469-470.

23. Ahmad M, Nazli S, Anwar M (1989) Studies on Tannins from Barks of Pinus roxburghii. Jour Chem Soc Pak 11: 213-217.

24. Chatterjee A, Dhara KP, Rej RN, PC G (1977) Hexacosylferulate, a phenolic constituent of Pinus roxburghii. Phytochemistry 16: 397-398.

25. Vessal M, Hemmati M, Vasei M (2003) Antidiabetic effects of quercetin in streptozocin-induced diabetic rats. Comp Biochem Physiol C Toxico Pharmacol 135C: 357-364. 